\title{
PERTUMBUHAN DAN HASIL RUMPUT GAJAH KATE (Pennisetum purpureum cv. Mott) PADA JENIS DAN DOSIS PUPUK KANDANG
}

\author{
Leni Noralita, N. M. Witariadi, I W. Wirawan \\ Program Studi Sarjana Peternakan, Fakultas Peternakan, Universitas Udayana \\ JIn.P.B. Sudirman,Denpasar, Bali \\ e-mail: leninoralita260198@gmail.com
}

\begin{abstract}
ABSTRAK
Penelitian bertujuan untuk mengetahui pertumbuhan dan hasil rumput gajah kate (Pennisetum purpureum cv. Mott) yang diberi beberapa jenis dan dosis pupuk kandang, serta untuk mengetahui interaksi antara jenis dan dosis pupuk kandang terhadap pertumbuhan dan hasil rumput gajah kate (Pennisetum purpureum cv. Mott). Penelitian dilakukan di Rumah Kaca, Stasiun Penelitian Sesetan, Fakultas Peternakan, Universitas Udayana di Jalan Raya Sesetan Gang Markisa. Penelitian berlangsung selama 8 minggu, menggunakan rancangan acak lengkap (RAL) pola faktorial. Faktor pertama terdiri atas jenis pupuk yaitu: Pupuk kandang sapi (S), Pupuk kandang ayam (A), pupuk kandang sapi dan ayam (SA), faktor kedua terdiri atas dosis pupuk yaitu: o ton/ha (Do), 10 ton/ha (D10), 20 ton/ha (D20), 30 ton/ha (D30) dan setiap perlakuan diulang sebanyak tiga kali, sehingga terdapat 36 unit percobaan. Variabel yang diamati yaitu variabel pertumbuhan, variabel hasil dan variabel karakteristik tumbuh tanaman. Hasil penelitian menunjukkan bahwa terjadi interaksi antara jenis dan dosis pupuk kandang terhadap variabel jumlah anakan. Perlakuan jenis pupuk kotoran ayam berpengaruh nyata pada variabel jumlah daun, jumlah anakan, lingkar rumpun, berat kering batang,dan berat kering total hijauan, sedangkan perlakuan dosis 20 ton/ha memberikan pengaruh nyata pada tinggi tanaman, jumlah daun,jumlah anakan, lingkar rumpun, berat kering daun berat kering total hijauan, nisbah berat kering total hijauan dengan berat kering akar, dan luas daun. Berdasarkan hasil penelitian dapat disimpulkan bahwa terjadi interaksi antara jenis dan dosis pupuk kandang terhadap variabel jumlah anakan, dan perlakuan jenis pupuk kotoran ayam dan dosis 20 ton/ha memberikan respon terbaik pada pertumbuhan dan hasil rumput gajah kate (Pennisetum purpureum $\mathrm{cv}$. Mott).
\end{abstract}

Kata kunci: pertumbuhaan, hasil, rumput gajah kate, jenis, dosis, pupuk

\section{GROWTH AND YIELD OF PENNISETUM PURPUREUM CV. MOTT THAT GIVEN SOME TYPES AND DOSAGE OF MANURE}

\begin{abstract}
The study aims to determine the growth and yield of Pennisetum purpureum cv. Mott given several types and doses of manure, as well as to determine the interaction between types and doses of manure on growth and yield Pennisetum purpureum cv. Mott. The study was conducted at the Greenhouse, Sesetan Research Station, Faculty of Animal Husbandry, Udayana University on Jalan Raya Sesetan Gang Markisa. The study lasted for 8 weeks, using completely design (CRD) factorial pattern. First factor was type of fertilizer: cow manure (S), chicken manure (A), combination of cow and chicken (SA), second factor was the dose of fertilizer, : o ton / ha (Do), 10 tons / ha (D10), 20 ton /ha (D20), 30 ton/ha (D30 and each treatment was repeated three times, so there are 36 units trial. Variables observed were growth, yield and of the growth. Results of the study showed there was an interaction between the type and dose of manure on variable number of tillers. Treatment of type of manure chicken significant effect on in a variable number of leaves, number of tillers ,circumference clumps, stems dry weight, dry weight total forage, while the treatment dose of 20 ton / ha gives significant effect on height of plants, number of leaves, number of tillers, circumference clumps, leaf dry weight total forage, dry weight total forage dry weight and root dry weight ratio and leaf area. Based on the results of the research can be concluded that there was an interaction between the type and dose of manure on variable number of tillers, and treatment of the type of chicken manure and a dose of 20 ton/ha give the best response to the growth and yield of Pennisetum purpureum cv. Mott .
\end{abstract}

Keywords: growth, yield, Pennisetum purpureum cv. Mott, type of manure 


\section{PENDAHULUAN}

Peningkatan populasi ternak khususnya ternak ruminansia perlu didukung dengan ketersediaan hijauan pakan baik dari segi kuantitas dan kualitasnya. Hijauan pakan mempunyai peranan penting bagi ternak ruminansia dan merupakan pakan utama yang berfungsi untuk menjaga kelangsungan produksi. Penyediaan hijauan pakan masih menjadi kendala sampai saat ini, terutama pada lahan kering, sehingga ketersediaannya menjadi terbatas. Penanaman hijauan pakan pada lahan yang subur menghasilkan produktivitas pakan yang lebih baik, jika dibandingkan dengan lahan kritis atau kurang subur. Keberhasilan pertumbuhan hijauan pakan membutuhkan dukungan lingkungan fisik tanah dan iklim yang ideal (Sumarsono et al., 2005).

Jenis tanaman pakan yang berpotensi dikembangkan adalah rumput gajah kate (Pennisetum purpureum cv. Mott). Rumput gajah kate merupakan jenis rumput unggul, karena produktivitas dan kandungan zat gizi cukup tinggi serta memiliki palatabilitas yang tinggi bagi ternak ruminansia. Pola pertumbuhannya rumput ini memiliki karakter unik dengan pertumbuhan daunnya lebih mengarah ke samping. Rumput gajah kate (Pennisetum purpureum cv. Mott) memiliki beberapa keunggulan yaitu: pertumbuhan cepat, berbulu halus, daun lembut, batang lunak, disukai ternak dan regrowth (pertumbuhan kembali) yang cepat. Keunggulan lain adalah produksi hijauan tinggi, dengan kandungan protein 10-15\% dan kandungan serat kasar rendah (Urribari et al., 2005).

Peningkatan pertumbuhan dan produksi rumput gajah kate dapat dicapai dengan melakukan pemeliharaan yang baik. Pemupukan dengan pupuk organik merupakan salah satu usaha yang dapat dilakukan untuk memenuhi kebutuhan unsur hara yang diperlukan oleh tanaman guna meningkatkan produksi hijauan. Pemupukan dengan pupuk kandang merupakan langkah yang tepat dalam upaya menjaga kesuburan dan kesehatan tanah, serta mengurangi dampak negatif dari penggunaan pupuk anorganik. Pupuk organik dapat berbentuk padat atau cair yang digunakan mensuplai bahan organik untuk memperbaiki sifat, kimia, dan biologi tanah (Suriadikarta dan Simanungkalit, 2006). Beberapa jenis pupuk organik yang umum digunakan adalah pupuk kandang kotoran sapi, kotoran ayam dan kombinasi antara pupuk kotoran sapi dan kotoran ayam.

Havlin et al. (1999) menyatakan bahwa pemberian pupuk kandang dapat menghemat pupuk N, penggunaan pupuk kandang juga dapat mengurangi penggunaan pupuk $\mathrm{P}$ dan $\mathrm{K}$ serta meningkatkan hasil produksi tanaman rumput gajah. Hasil penelitian
Trisnadewi et al. (2012) mendapatkan bahwa pemberian pupuk kandang ayam broiler, kuda dan babi pada dosis 20 ton/ha menghasilkan produksi berat kering total hijauan jagung manis tertinggi dibandingkan pemberian 10 dan 30 ton/ha. Hasil penelitian Widana et al.(2004) pada rumput benggala (Panicum maximum cv. Trichoglume) mendapatkan bahwa pemberian pupuk organik dosis 20 ton/ha dapat meningkatkan variabel pertumbuhan.

Berdasarkan uraian di atas, perlu dilakukan penelitian untuk mengetahui pertumbuhan dan hasil rumput gajah kate (Pennisetum purpureum cv. Mott) yang diberi beberapa jenis dan dosis pupuk kandang.

\section{MATERI DAN METODE}

Percobaan dilakukan di Rumah Kaca, Stasiun penelitian Fakultas Peternakan Universitas Udayana yang digunakan adalah jenis rumput gajah kate (Pennisetum purpureum cv. Mott). Tanah yang digunakan diambil dari lokasi Stasiun Penelitian Fakultas Peternakan, Desa Pengotan, Kabupaten Bangli, yang memiliki tekstur pasir berlempung dengan kandungan $\mathrm{C}$ organik 1,22\% (rendah), $\mathrm{N}$ total 0,13\% (rendah), P tersedia 45,43 ppm (sangat tinggi), kadar air kering udara (Ku) 4,07\% dan kapasitas lapang $30,52 \%$. Tanah yang akan dipakai terlebih dahulu dikering udarakan, kemudian ditumbuk halus, selanjutnya diayak dengan tujuan agar ukuran partikel tanah merata. Tanah ditimbang dan dimasukkan ke dalam pot yang masing-masing diisi sebanyak $4 \mathrm{~kg}$ tanah kering udara. Tanah dalam pot kemudian disiram dengan air sampai kapasitas lapang.

Percobaan menggunakan pot berbahan dasar plastik yang berdiameter $26 \mathrm{~cm}$ dan tinggi $19 \mathrm{~cm}$ sebanyak 36 buah. Pupuk yang digunakan yaitu pupuk kotoran ayam yang berasal dari feses ayam dan kotoran sapi yang diberasal dari feses sapi. Analisa kandungan unsur hara dilakukan di Laboratorium Biosain Politeknik Negeri Jember. Pupuk kotoran ayam mengandung unsur N (0,794\%), P2O5 (1,390\%), K2O (2,964\%) dan C-organik (16,159\%), sedangkan pupuk kotoran sapi unsur N (1,390\%), P2O5 (1,890\%), K (3,081\%), dan C-organik (13,747\%).

Rancangan percobaan yang dipergunakan adalah rancangan acak lengkap (RAL) pola faktorial. Faktor pertama yaitu jenis pupuk pupuk kandang sapi (S), pupuk kandang ayam (A) dan kombinasi pupuk kandang ayam 50\% dan pupuk kandang sapi 50\% dan faktor kedua yaitu dosis pupuk o ton/ha (Do), 10 ton/ha (D10), 20 ton/ha (D20), 30 ton/ha (D30). Kombinasi perlakuan diulang tiga kali, sehingga pot yang digunakan adalah 36 pot. Peubah yang meliputi: tinggi tanaman, jumlah daun, jumlah batang, lingkar rumpun, berat kering daun, berat kering batang, berat 
kering total hijauan, berat kering akar, nisbah berat kering daun dengan berat kering batang, nisbah berat kering total hijauan dengan berat kering akar, dan luas daun per pot.

\section{HASIL DAN PEMBAHASAN}

Hasil penelitian menunjukkan bahwa terjadi interaksi antara jenis pupuk dan dosis pupuk kandang. Interaksi antara perlakuan jenis dan dosis pupuk kandang berpengaruh nyata terhadap variabel jumlah anakan (Tabel.1) sedangkan terhadap variabel yang lainnya memberikan hasil yang sama. Keadaan tersebut menunjukkan bahwa antara faktor jenis pupuk organik dan faktor dosis pupuk organik dapat secara bersama-sama atau sendiri-sendiri dalam mempengaruhi pertumbuhan dan produksi tanaman rumput gajah kate (Pennisetum purpureum $\mathrm{cv}$. Mott). Menurut Gomez dan Gomez (1995) bahwa dua faktor perlakuan dikatakan berinteraksi apabila pengaruh suatu faktor perlakuan berubah pada saat perubahan taraf faktor perlakuan lainnya.

Perlakuan pemberian jenis pupuk kotoran ayam pada rumput Pennisetum purpureum cv. Mott dapat memberikan hasil terbaik pada variabel tinggi tanaman, jumlah daun, jumlah anakan dan lingkar rumpun (Tabel 1). Hal ini disebabkan oleh pupuk kotoran ayam merupakan pupuk yang bersifat panas yaitu pupuk kandang yang penguraiannya oleh mikroorganisme berlangsung dengan cepat dan cepat menjadi matang. Proses penguraian bahan organik pada kondisi seperti ini dapat menyediakan unsur hara lebih cepat didalam tanah yang selanjutnya akan dimaanfatkan oleh tanaman mendukung pertumbuhan awal tanaman yaitu pertumbuhan vegetatif. Pertumbuhan vegetatif pada tanaman seperti memperbanyak tumbuhnya akar, bertambah tinggi, meningkatnya jumlah daun dan jumlah anakan, serta lingkar rumpun semakin melebar. Harjadi (1996) menyatakan bahwa pada fase vegetatif terjadi tiga proses penting, yaitu pembelahan sel, perpanjangan sel dan tahap pertama diferensiasi sel yang berhubungan dengan perkembangan akar, daun dan batang.

Pupuk kotoran ayam juga meningkatkan hasil rumput gajah kate (Pennisetum purpureum cv. Mott). Hal ini disebabkan pupuk kotoran ayam mempunyai C-organik yang lebih tinggi. C-organik (bahan organik) merupakan bagian dari tanah yang merupakan suatu sistem kompleks dan dinamis, yang bersumber dari sisa tanaman dan atau binatang yang terdapat di dalam tanah yang terus menerus mengalami perubahan bentuk, karena dipengaruhi oleh faktor biologi, fisika, dan kimia. Hal ini didukung oleh pendapat Tufaila et al. (2014) yang menyatakan bahwa dengan memberikan bahan organik atau pupuk
Tabel 1 Pertumbuhan Rumput Gajah Kate (Pennisetum purpureum cv. Mott) yang Diberi Beberapa Jenis dan Dosis Pupuk Kandang

\begin{tabular}{|c|c|c|c|c|c|c|c|}
\hline \multirow[t]{2}{*}{ Variabel } & \multirow{2}{*}{$\begin{array}{c}\text { Jenis } \\
\text { pupuk } \\
\text { kan- } \\
\text { dang1) }\end{array}$} & \multicolumn{4}{|c|}{$\operatorname{Dosis}^{2)}$} & \multirow[b]{2}{*}{ Rataan } & \multirow[b]{2}{*}{ SEM 3 ) } \\
\hline & & Do & D10 & D20 & D30 & & \\
\hline \multirow{4}{*}{$\begin{array}{l}\text { Tinggi } \\
\text { tanaman } \\
(\mathrm{cm})\end{array}$} & S & 15,33 & 19,00 & 20,67 & 19,00 & $18,50^{\mathrm{X}}$ & 1,58 \\
\hline & A & 17,00 & 21,00 & 24,33 & 20,67 & $20,75^{\mathrm{X}}$ & \\
\hline & SA & 16,00 & 18,00 & 23,33 & 20,33 & $19,45^{\mathrm{X}}$ & \\
\hline & Rataan & $16,11^{\mathrm{C} 4)}$ & $19,33^{\mathrm{B}}$ & $22,78^{\mathrm{A}}$ & $20,00^{B}$ & & \\
\hline \multirow{4}{*}{$\begin{array}{c}\text { Jumlah } \\
\text { daun } \\
\text { (helai) }\end{array}$} & S & 12,33 & 22,33 & 25,67 & 29,33 & $22,42^{\mathrm{Y}}$ & 3,84 \\
\hline & A & 11,67 & 28,33 & 37,67 & 37,00 & $28,67^{X}$ & \\
\hline & SA & 11,33 & 15,67 & 34,33 & 22,67 & $21,00^{Y}$ & \\
\hline & Rataan & $11,78^{\mathrm{B}}$ & $22,11^{\mathrm{B}}$ & $32,5^{6^{\mathrm{A}}}$ & $29,67^{\mathrm{A}}$ & & \\
\hline \multirow{4}{*}{$\begin{array}{l}\text { Jumlah } \\
\text { anakan } \\
\text { (batang) }\end{array}$} & S & $5,33^{h}$ & $8, \mathrm{oo}^{\mathrm{ef}}$ & $11, \mathrm{OO}^{\mathrm{bc}}$ & $9,33^{\mathrm{de}}$ & $8,42^{Y}$ & 0,41 \\
\hline & A & $5,33^{h}$ & $7,33 \mathrm{fg}$ & $13, \mathrm{OO}^{\mathrm{a}}$ & $11,67^{b}$ & $9,33^{\mathrm{X}}$ & \\
\hline & SA & $6,00^{g h}$ & $7,00^{\text {fg }}$ & $14, \mathrm{OO}^{\mathrm{a}}$ & $10,00^{\mathrm{cd}}$ & $9,25^{\mathrm{X}}$ & \\
\hline & Rataan & $5,56^{\mathrm{D}}$ & $7,44^{\mathrm{C}}$ & $12,67^{\mathrm{A}}$ & $10,33^{\mathrm{B}}$ & & \\
\hline \multirow{4}{*}{$\begin{array}{l}\text { Lingkar } \\
\text { rumpun } \\
(\mathrm{cm})\end{array}$} & S & 14,67 & 19,00 & 23,33 & 22,67 & $19,92^{X}$ & 4,04 \\
\hline & A & 14,67 & 29,00 & 45,67 & 23,33 & $28,17^{X}$ & \\
\hline & SA & 13,67 & 21,67 & 32,33 & 27,33 & $23,75^{\mathrm{X}}$ & \\
\hline & Rataan & $14,33^{\mathrm{C}}$ & $23,22^{\mathrm{B}}$ & $33,78^{\mathrm{A}}$ & $24,44^{\mathrm{B}}$ & & \\
\hline
\end{tabular}

Keterangan:

1) $\mathrm{S}=$ pupuk kandang sapi, $\mathrm{A}=$ pupuk kandang ayam, $\mathrm{SA}=$ pupuk kandang sapi dan pupuk kandang ayam

Do $=0$ ton/ha, D1o $=10$ ton/ha, D20 $=20$ ton $/$ ha, D3o $=30$ ton $/$ ha

3) $\mathrm{SEM}=$ Standard Error of theTreatment Means

4) Nilai dengan huruf kapital berbeda pada baris dan kolom yang sama menunjukkan berbeda nyata $(\mathrm{P}<0,05)$ dan nilai dengan huruf kecil yang sama pada baris dan kolom yang sama menunjukkan berbeda tidak nyata $(\mathrm{P}>0,05)$

organik yang C-organik nya tinggi maka secara tidak langsung telah menyumbangkan C-organik tanah, sehingga C-organik tanah juga meningkat dan dapat memperbaiki struktur tanah. Menurut Bot dan Benites (2005) menyatakan bahwa bahan organik dapat memperbaiki struktur tanah dan berfungsi mengadsorpsi dan menahan unsur hara dalam bentuk tersedia bagi tanaman. Unsur hara yang tersedia ini digunakan oleh tanaman untuk meningkatakan hasil berat kering hijauan. Tingginya C-organik yang menyebabkan peningkatan unsur hara dalam tanah menyebabkan pertumbuhan akar menjadi sama, karena unsur hara yang diserap sudah mencukupi jadi akar tidak berkembang lagi untuk mencari unsur hara ke tempat lain. Hal ini didukung oleh pendapat Lal (2004) yang menyatakan bahwa C-organik tanah yang tinggi dapat membantu keberlanjutan kesuburan tanah, melindungi kualitas tanah dan air yang terkait dalam siklus hara, air dan biologi.

Nisbah berat kering daun dengan berat kering batang dan nisbah berat kering total hijauan dengan berat kering akar rumput gajah kate (Pennisetum purpureum cv. Mott) memberikan hasil yang sama pada ketiga jenis pupuk. Nisbah berat kering daun dengan berat kering batang di pengaruhi oleh nilai berat kering daun dan berat kering batang. Bila nilai berat kering daun lebih rendah dari nilai berat kering batang, maka nilai nisbah berat kering daun dengan berat kering batangnya kecil. Nilai ini menunjukkan 
Tabel 2. Hasil Rumput Gajah Kate (Pennisetum purpureum cv. Mott) yang diberi Beberapa Jenis dan Dosis Pupuk Kandang

\begin{tabular}{|c|c|c|c|c|c|c|c|}
\hline \multirow[t]{2}{*}{ Variabel } & \multirow{2}{*}{$\begin{array}{c}\text { Jenis } \\
\text { Pupuk } \\
\text { Kan- } \\
\text { dang1) }\end{array}$} & \multicolumn{4}{|c|}{$\operatorname{Dosis}^{2)}$} & \multirow[b]{2}{*}{ Rataan } & \multirow[b]{2}{*}{ SEM $\left.{ }^{3}\right)$} \\
\hline & & Do & D10 & D2O & D3o & & \\
\hline \multirow{4}{*}{$\begin{array}{l}\text { Berat } \\
\text { kering } \\
\text { daun } \\
(\mathrm{g})\end{array}$} & $S$ & 1,87 & 5,93 & 8,23 & 7,07 & $5,78^{\mathrm{X}}$ & \multirow{3}{*}{ 2,33 } \\
\hline & A & 2,00 & 10,68 & 14,93 & 10,43 & $9,50^{\mathrm{X}}$ & \\
\hline & SA & 2,27 & 4,83 & 11,30 & 5,47 & $5,97^{\mathrm{X}}$ & \\
\hline & Rataan & $2,04^{\mathrm{C} 4)}$ & $7,13^{\mathrm{B}}$ & $11,49^{\mathrm{A}}$ & $7,66^{\mathrm{AB}}$ & & \\
\hline \multirow{4}{*}{$\begin{array}{c}\text { Berat } \\
\text { kering } \\
\text { batang } \\
\text { (g) }\end{array}$} & $S$ & 1,23 & 4,67 & 6,23 & 4,33 & $4,12^{\mathrm{Y}}$ & \multirow{3}{*}{1,92} \\
\hline & A & 11,53 & 11,87 & 10,30 & 7,97 & $10,42^{X}$ & \\
\hline & SA & 2,60 & 3,43 & 6,80 & 10,33 & $5,79^{\mathrm{Y}}$ & \\
\hline & Rataan & $5,12^{\mathrm{A}}$ & $6,66^{\mathrm{A}}$ & $7,78^{\mathrm{A}}$ & $7,54^{\mathrm{A}}$ & & \\
\hline \multirow{4}{*}{$\begin{array}{c}\text { Berat } \\
\text { kering } \\
\operatorname{akar}(g)\end{array}$} & $S$ & 14,70 & 9,83 & 25,33 & 15,37 & $16,31^{X}$ & \multirow{4}{*}{7,16} \\
\hline & A & 12,33 & 17,83 & 16,90 & 18,50 & $16,39^{X}$ & \\
\hline & SA & 10,67 & 6,27 & 26,30 & 21,37 & $16,15^{\mathrm{X}}$ & \\
\hline & Rataan & $12,57^{\mathrm{A}}$ & $11,31^{\mathrm{A}}$ & $22,84^{\mathrm{A}}$ & $18,41^{\mathrm{A}}$ & & \\
\hline \multirow{4}{*}{$\begin{array}{l}\text { Berat } \\
\text { kering } \\
\text { total } \\
\text { hijauan } \\
\text { (g) }\end{array}$} & $S$ & 3,10 & 10,60 & 14,47 & 11,27 & $9,86^{\mathrm{Y}}$ & \multirow{3}{*}{7,70} \\
\hline & A & 6,90 & 22,50 & 25,23 & 18,40 & $18,26^{\mathrm{X}}$ & \\
\hline & SA & 4,87 & 8,27 & 18,10 & 15,80 & $11,76^{\mathrm{Y}}$ & \\
\hline & Rataan & $4,96^{\mathrm{B}}$ & $13,79^{\mathrm{B}}$ & $19,27^{\mathrm{A}}$ & $15,16^{\mathrm{AB}}$ & & \\
\hline \multicolumn{8}{|c|}{$\begin{array}{l}\text { Keterangan: } \\
\text { 1) } \mathrm{S}=\text { pupuk kandang sapi, } \mathrm{A}=\text { pupuk kandang ayam, } \mathrm{SA}=\text { pupuk kandang } \\
\text { sapi dan pupuk kandang ayam } \\
\text { 2) } \mathrm{DO}=\mathrm{O} \text { ton/ha, D10 }=10 \text { ton/ha, D2O }=2 \mathrm{O} \text { ton } / \mathrm{ha}, \mathrm{D} 3 \mathrm{O}=30 \text { ton } / \mathrm{ha} \\
\text { 3) } \mathrm{SEM}=\text { Standard Error of theTreatment Means } \\
\text { 4) Nilai dengan huruf kapital berbeda pada baris dan kolom yang sama } \\
\text { menunjukkan berbeda nyata }(\mathrm{P}<\mathrm{0}, \mathrm{O} \text { ) }) \text { dan nilai dengan huruf kecil yang } \\
\text { sama pada baris dan kolom yang sama menunjukkan berbeda tidak } \\
\text { nyata }(\mathrm{P}>0,05)\end{array}$} \\
\hline
\end{tabular}

kualitas hijauan pakan yaitu hijauan dikatakan memiliki kualitas baik apabila nisbahnya memberikan hasil yang tinggi.

Pemberian dosis 20 ton/ha memberikan hasil paling baik terhadap variabel pertumbuhan, variabel hasil dan variabel karakteristik tumbuh tanaman.
Hal ini disebabkan dosis pupuk yang diberikan dapat menyokong pertumbuhan tanaman. Pertumbuhan tanaman dapat berlangsung dengan baik, bila unsur hara yang tersedia mencukupi untuk pertumbuhan. Unsur hara yang paling dibutuhkan adalah nitrogen yang digunakan untuk mendukung pertumbuhan awal. Hal ini didukung oleh pendapat Soepardi (1983) yang menyatakan bahwa peran utama nitrogen bagi tanaman adalah untuk merangsang pertumbuhan tanaman secara keseluruhan, khususnya batang, cabang dan daun. Zuchri (2006) menyatakan bahwa semakin baik pertumbuhan tanaman dan semakin banyak unsur hara serta air yang terserap maka bobot kering tanaman semakin berat. Hasil penelitian Trisnadewi et al. (2012) bahwa pemberian pupuk kandang ayam broiler, kuda dan babi pada dosis 20 ton/ha menghasilkan pertumbuhan dan hasil berat kering total hijauan jagung manis tertinggi dibandingkan pemberian 10 dan 30 ton/ha.

Hakim et al. (1986) menyatakan unsur $\mathrm{N}$ berfungsi dalam pembentukan sel-sel klorofil dimana klorofil berguna dalam proses fotosintesis sehingga dibentuk energi yang diperlukan sel untuk aktifitas pembelahan, pembesaran dan pemanjangan. Klorofil terdapat pada hijau daun, dimana semakin banyak jumlah daun yang diimbangi luas daun yang lebar, akan berdampak pada proses fotosintesis berlangsung dengan baik dan mengahasilkan karbohidrat yang tinggi. Dwijoseputro (1980) menyatakan bahwa fotosintesis merupakan proses pembentukan karbohidrat dari karbondioksida $\left(\mathrm{CO}_{2}\right)$ dan air dibantu dengan energi cahaya serta klorofil. Laju fotosintesis dipengaruhi oleh cahaya, $\mathrm{CO}_{2}$, air, suhu, (Gardner et al., 1991) dan luas daun (Kimball, 1992). Hasil fotosintesis ini digunakan oleh

Tabel 3. Karakteristik Rumput Gajah Kate (Pennisetum purpureum cv. Mott) yang Diberi Beberapa Jenis dan Dosis Pupuk Kandang

\begin{tabular}{|c|c|c|c|c|c|c|c|}
\hline \multirow{2}{*}{ Variabel } & \multirow{2}{*}{$\begin{array}{l}\text { Jenis pupuk } \\
\text { kandang }\end{array}$} & \multicolumn{4}{|c|}{ Dosis $^{2)}$} & \multirow{2}{*}{ Rataan } & \multirow{2}{*}{ SEM 3$)$} \\
\hline & & Do & D10 & D20 & D30 & & \\
\hline \multirow{4}{*}{$\begin{array}{c}\text { Nisbah berat kering daun dengan } \\
\text { berat kering batang }\end{array}$} & $\mathrm{S}$ & 1,82 & 1,45 & 1,26 & 1,53 & $1,52^{X}$ & 0,46 \\
\hline & A & 1,41 & 0,89 & 1,75 & 1,39 & $1,36^{\mathrm{X}}$ & \\
\hline & SA & 1,32 & 1,06 & 1,75 & 0,54 & $1,17^{X}$ & \\
\hline & Rataan & $1,52^{\mathrm{A} 4)}$ & $1,13^{\mathrm{A}}$ & $1,59^{\mathrm{A}}$ & $1,15^{\mathrm{A}}$ & & \\
\hline \multirow{4}{*}{$\begin{array}{c}\text { Nisbah berat kering total hijauan } \\
\text { dengan berat kering akar }\end{array}$} & $\mathrm{S}$ & 0,23 & 1,86 & 0,85 & 2,31 & $1,31^{\mathrm{X}}$ & 0,52 \\
\hline & $\mathrm{A}$ & 0,37 & 1,65 & 1,46 & 1,06 & $1,14^{\mathrm{X}}$ & \\
\hline & SA & 0,46 & 1,34 & 0,70 & 0,94 & $0,86^{\mathrm{X}}$ & \\
\hline & Rataan & $0,35^{\mathrm{B}}$ & $1,62^{\mathrm{A}}$ & $1, \mathrm{OO}^{\mathrm{AB}}$ & $1,44^{\mathrm{A}}$ & & \\
\hline \multirow[t]{4}{*}{ Luas daun per Pot $\left(\mathrm{cm}^{2}\right)$} & $\mathrm{S}$ & 2500,35 & 9663,77 & 9796,01 & 10091,33 & $32055,4^{X}$ & 4302,3 \\
\hline & A & 2093,66 & 10363,58 & $1745^{2,38}$ & 18449,74 & $48363,3^{\mathrm{X}}$ & \\
\hline & $\mathrm{SA}$ & 2099,62 & 12933,72 & 13184,18 & 7076,30 & $35297,8^{X}$ & \\
\hline & Rataan & $2231,21^{B}$ & $10987,02^{\mathrm{A}}$ & $13477,5^{2^{A}}$ & $11872,46^{\mathrm{A}}$ & & \\
\hline
\end{tabular}

Keterangan:

1) $\mathrm{S}=$ pupuk kandang sapi, $\mathrm{A}=$ pupuk kandang ayam, $\mathrm{SA}=$ pupuk kandang sapi dan pupuk kandang ayam

2) $\mathrm{Do}=\mathrm{o}$ ton $/ \mathrm{ha}, \mathrm{D} 10=10 \mathrm{ton} / \mathrm{ha}, \mathrm{D} 20=20$ ton $/ \mathrm{ha}, \mathrm{D} 30=30$ ton $/ \mathrm{ha}$

3) $\mathrm{SEM}=$ Standard Error of theTreatment Means

4) Nilai dengan huruf kapital berbeda pada baris dan kolom yang sama menunjukkan berbeda nyata $(\mathrm{P}<0,05)$ dan nilai dengan huruf kecil yang sama pada baris dan kolom yang sama menunjukkan berbeda tidak nyata $(\mathrm{P}>0,05)$ 
tanaman untuk pertumbuhan dan meningkatkan hasil berat kering tanaman. Menurut Gardner et al. (1991) berat kering merupakan keseimbangan antara pengambilan karbon dioksida (fotosintesis) dan pengeluaran (respirasi), apabila respirasi lebih besar dari fotosintesis, berat kering tumbuhan akan berkurang begitu pula sebaliknya.

\section{SIMPULAN}

Berdasarkan hasil penelitian ini dapat disimpulkan bahwa rumput gajah kate (Pennisetum purpureum cv. Mott) yang diberi jenis pupuk kotoran ayam pada dosis 20 ton/ha memberikan pertumbuhan dan hasil yang paling baik. Terjadi interaksi antara jenis pupuk dan dosis pupuk kandang terhadap pertumbuhan rumput gajah kate (Pennisetum purpureum cv. Mott) pada variabel jumlah anakan.

\section{DAFTAR PUSTAKA}

Bot, A. and J. Benites, 2005. The importance of soil organic matter Key to drought-resistant soil and sustained food and production. FAO Soils Bulletin 80 Rome.

Dwidjoseputro.D. 1980. Pengantar fisiologi tumbuhan. Jakarta : Gramedia.

Garder, F. P ., R. B. Pearce dan L. R. Mitchell. 1991. Fisiologi Tanaman Budidaya (terjemahan). Universitas Indonesia (Press). Jakarta.

Gomez, KA dan Gomez, A.A. 1995. Prosedur Statistik untuk Penelitian Pertanian. Terjemahan E. Sjamsudin dan J.S. Baharsiah. UI-Press. Jakarta, halaman 87-219.

Hakim, N. Nyakpa, Lubis, Nugroho, Saul, A. Dida, G. B. Hong dan Balley. 1986. Dasar-dasar Ilmu Tanah. Universitas Lampung, Bandar Lampung.

Harjadi S. S. 1996. Pengantar Agronomi. Jakarta:PT. Gramedia Pustaka Utama.195 hal.

Kimball, J.. W. 1992. Biologi. Edisi 2 Jilid 1. Jakarta: Erlangga.
Lal, R. 2004. Soil Carbon Impact on Global Climate Change and Food Security. Science, 304: 16231627

Soepardi, G. 1983. Sifat dan Ciri Tanah. Fakultas Pertanian Institut Pertanian Bogor. Bogor.

Sumarsono. 2005. Peranan pupuk organik untuk perbaikan penampilan dan produksi hijauan rumput gajah pada tanah cekaman salinitas dan kemasaman.Makalah disajikan Pada Seminar Prospek Pengembangan Peternakan Tampa Limbah, Jurusan Produksi Ternak Fakultas Pertanian UNS, Surakarta 5 September 2005.

Surridikarta, dan R.D.M.Simanungkalit.2006. Pupuk organik dan pupuk Hayati. Balai Besar Penelitian dan Pengembangan Sumberdaya Lahan Pertanian. Bogor.

Trisnadewi, A. A. A. S., I Wayan Wijana dan T.G.O. Susila. 2012. Pengaruh jenis dan dosis pupuk kandang terhadap pertumbuhan dan produksi jagung manis (Zea mays Saccharata Sturt). Jurnal Pastura Vol 1 No. 2. Sumber: https://ojs. unud.ac.id/index.php/mip/article/view/1598.

Tufaila. M dan Alam, Syamsu. 2014. Karakteristik Tanah Dan Evaluasi Lahan Untuk Pengembangan Tanaman Padi Sawah di Kecamatan Oheo Kabupaten Konawe Utara. Jurnal ilmiah Volume 24 Nomor : 02 Mei 2014. Kendari

Wahyuningsih, I. 2004. Produktivitas Pueraria phaseoloides Var. Javanica Dipupuk Dengan Dosis Pupuk Kandang Dari Sapi yang Diberi Ransum Berkonsentrat Disuplementasi Ammonium Sulfat. Skripsi, Fakultas Peternakan Universitas Udayana, Denpasar.

Widana, G. A. A, N. G. K. Roni, dan A. A. A. S. Trisnadewi. 2015. Pertumbuhan dan produksi rumput benggala (Panicum maximum $c v$ Trichoglume) pada berbagai jenis dan dosis pupuk organik. E-Journal Peternakan Tropika Vol. 3 No. 2. Sumber: https://ojs.unud.ac.id/ index.php/tropika/article/view/18601. 